C-2 zum Sauerstoff in 2'-Stellung unbekannt ist.

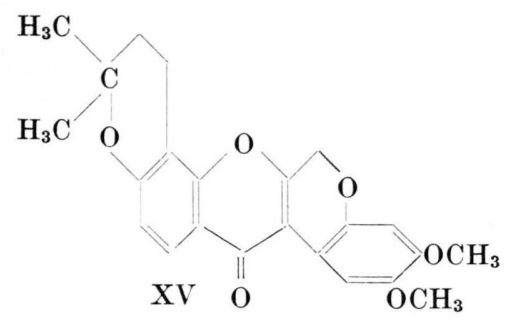

Die Arbeit wurde in dankenswerter Weise durch die Deutsche Forschungsgemeinschaft unter- stützt. Weiterhin danke ich dem F onds der Ch e mie und der Badischen Anilin- und Sodaf a b rik für Sachbeihilfen.

A n m. b. d. K o r r.: Wie mir Prof. Geissman, Los Angeles, mitteilte, hat er unabhängig von uns die Biogenese des Isoflavons Biochanin A untersucht (T. A. Geissman, J. W. Mason u. J. R. Rowe, Chem. and Ind., im Druck). Geissman kommt jedoch auf Grund seiner Ergebnisse zu dem Schluß, daß das Phenylalanin unter Verlust der Carboxylgruppe als $\mathrm{C}_{6}-\mathrm{C}_{2}$-Einheit in das Isoflavon eingebaut wird. Diese Auffassung ist aber mit unseren Ergebnissen nicht vereinbar. Der Grund für die Diskrepanz der Ergebnisse ist im Augenblick noch ungeklärt.

\title{
Vinyl Derivatives of some Metals and Nonmetals
}

\author{
By Bodo Bartocha, C. M. Douglas, and M. Y. Gray \\ Chemistry Division, U.S. Naval Ordnance Laboratory, Corona, California, U.S.A. \\ (Z. Naturforschg. 14 b, 809-811 [1959] ; eingegangen am 12. Oktober 1959)
}

\begin{abstract}
Die Darstellung von Vinylalkali-Verbindungen, Vinylbor- und Vinylphosphor-halogeniden mit Hilfe von Divinylzink, Divinylquecksilber und Tetravinylblei wird beschrieben. Bei der Reaktion von Tetravinylblei mit Phosphortrichlorid oder Phosphortribromid konnte neben den Vinylphosphorhalogeniden auch das entsprechende Divinylblei-dihalogenid isoliert werden.
\end{abstract}

The recently reported tetravinyllead ${ }^{1}$ and divinylzinc $^{2}$, and the previously synthesized divinylmercury ${ }^{3}$ were utilized as vinylation agents for the preparation of vinyl-alkali compounds and the vinylhalides of boron, aluminium, and phosphorus.

\section{Group I}

Seyferth and Weiner ${ }^{4}$ published the first method for the synthesis of vinyllithium by reacting tetravinyltin with phenyllithium. We would like to supplement this by reporting a new and general procedure for the preparation of vinyl derivatives of Group I elements.

We found that alkali-metal dispersions in ether, pentane, mineral oil, etc., react quite readily with divinylmercury to give the vinyl-alkali compounds in good yields:

$$
2 \mathrm{Li}(\mathrm{Na}, \mathrm{K})+\mathrm{Vi}_{2} \mathrm{Hg}^{*} \rightarrow 2 \mathrm{ViLi}(\mathrm{Na}, \mathrm{K})+\mathrm{Hg} .
$$

An alternate method is the reaction of alkali-metal dispersions with vinylchloride or vinylbromide. This

1 B. Bartocha and M. Y. Gray, Z. Naturforschg. 14 b, 350 [1959].

2 B. Bartocha, H. D. Kaesz and F. G. A. Stone, Z. Naturforschg. 14 b, 352 [1959]. synthesis has to be carried out at a lower temperature (between -40 and $0{ }^{\circ} \mathrm{C}$ depending on the solvent used) to prevent dehydrohalogenation. As may be guessed, these compounds are extremely reactive. Thermal decomposition takes place readily; sometimes rather spontaneously. Solutions of the vinylalkali compounds and also the solvent free materials, slowly decompose at room temperature even under an inert atmosphere.

\section{Group II}

Since the preparation of divinylmercury and divinylzinc was relatively simple, the next and obvious thing to do was to try to synthesize divinylcadmium. Thus far, all attempts to obtain this compound have been unsuccessful. Reactions between cadmium chloride, cadmium bromide and vinylmagnesium chloride or vinylmagnesium bromide in tetrahydrofuran, or vinyllithium in ether did not yield any vinylcadmium derivatives. In most cases, only metallic cadmium was formed.

3 B. Bartocha and F. G. A. Stone, Z. Naturforschg. 13 b, 347 [1958].

4 D. Seyferth and M. A. Weiner, Chem. and Ind. 1959, 402.

*Vi refers to the vinyl-group: $\mathrm{CH}_{2}=\mathrm{CH}-$. 


\section{Group III}

Of the vinylboron halides, only vinylboron difluoride has been described in detail previously ${ }^{5}$. We wish to report that vinylboron dichloride, $\mathrm{ViBCl}_{2}$ b. p. $45^{\circ} \mathrm{C} / 750 \mathrm{~mm} \mathrm{Hg}$, and vinylboron dibromide, $\mathrm{ViBBr}_{2}$ b. p. $35^{\circ} \mathrm{C} / 50 \mathrm{~mm} \mathrm{Hg}$, may be prepared by reacting divinylzinc with the appropriate boron trihalide. The exothermic reaction proceeds readily at room temperature or on mild warming. Instead of divinylzinc, the more easily handled divinylmercury may also be used. The rate of reaction is somewhat slower in this case. When divinylmercury was employed, the reaction proceeded according to:

$$
\mathrm{BX}_{3}+\mathrm{Vi}_{2} \mathrm{Hg} \rightarrow \mathrm{ViBX}_{2}+\mathrm{ViHgX}
$$

and the vinylmercury halide was isolated. When divinylzinc was used, however, no evidence of a vinylzinc halide could be found. Reduction of the vinylboron dihalides with metal hydrides leads to the formation of polymeric materials.

Although much effort has been devoted to the synthesis of organo-aluminum compounds, no vinylaluminum derivatives have been reported in the literature thus far. Reacting divinylmercury, divinylzinc, and tetravinyllead or a vinylalkali compound with aluminum metal, aluminum halides, and aluminum hydrides has made possible the preparation of a number of vinylaluminum derivatives not known before. Methods and experimental details of this work were reported elsewhere ${ }^{6}$ since this is beyond the scope of the present communication.

\section{Group V}

Some vinyl halides of elements of Group V have been reported previously. MAIER and coworkers ${ }^{7}$ prepared vinyl halides of arsenic, antimony, and bismuth by redistribution reactions using a trivinylmetal compound and an appropriate metal halide. Vinyldichlorophosphine, $\mathrm{ViPCl}_{2}$, was synthesized by reacting divinylmercury with phosphorus trichloride ${ }^{5}$. An extension of the latter method and the availability of tetravinyllead has enabled us to prepare vinyldibromophosphine, $\mathrm{ViPBr}_{2}$, and divinylchlorophosphine, $\mathrm{Vi}_{2} \mathrm{PCl}$. Vinyldibromophosphine (b. p. $60{ }^{\circ} \mathrm{C} / 20 \mathrm{~mm} \mathrm{Hg}$ ) is formed according to:
a. $\mathrm{Vi}_{2} \mathrm{Hg}+\mathrm{PBr}_{3} \rightarrow \mathrm{ViPBr}_{2}+\mathrm{ViHgBr}$, or
b. $\mathrm{Vi}_{4} \mathrm{~Pb}+2 \mathrm{PBr}_{3} \rightarrow 2 \mathrm{ViPBr}_{2}+\mathrm{Vi}_{2} \mathrm{PbBr}_{2}$.

5 B. Bartocha, F. E. Brinckman, H. P. Kaesz and F. G. A. Stone, Proc. chem. Soc. 1958, 116.

- B. Bartocha, A. J. Bilbo, D. E. Bublitz and M. Y. Gray, Abstracts IUPAC Meeting, Sept. 1959, Munich, Germany.
Divinylchlorophosphine (b.p. $38-42{ }^{\circ} \mathrm{C} / 20 \mathrm{~mm} \mathrm{Hg}$ ) was prepared by the reaction sequence:

a. $\mathrm{Vi}_{4} \mathrm{~Pb}+2 \mathrm{PCl}_{3} \rightarrow 2 \mathrm{ViPCl}_{2}+\mathrm{Vi}_{2} \mathrm{PbCl}_{2}$, b. $\mathrm{Vi}_{4} \mathrm{~Pb}+2 \mathrm{ViPCl}_{2} \rightarrow 2 \mathrm{Vi}_{2} \mathrm{PCl}+\mathrm{Vi}_{2} \mathrm{PbCl}_{2}$.

The first step was carried out without use of a solvent, usually with a slight excess of $\mathrm{PCl}_{3}$. The second stage of the reaction should be carried out in a high boiling liquid; for instance, pentachloroethane or mineral oil. We would like to note, that even a large excess of divinylmercury or divinylzinc refluxed with phosphorus trichloride does not yield the divinyl halide, $\mathrm{Vi}_{2} \mathrm{PCl}$, but the monovinyl halide $\mathrm{ViPCl}_{2}$. The final vinylation step can only be accomplished by using tetravinyllead. As would be expected, upon reduction of $\mathrm{ViPCl}_{2}$ or $\mathrm{Vi}_{2} \mathrm{PCl}$ with metal hydrides, the corresponding phosphines are formed ${ }^{8}$.

\section{Methods * \\ Preparation of Vinylalkalimetal Com pounds}

A. Vinylalkalimetal compounds prepared by reacting an alkali metal with divinylmercury: Lithium metal $(6.9 \mathrm{~g}, 1 \mathrm{~mole})$ in form of a dispersion in mineral oil was placed into a reaction flask fitted with stirrer, dropping funnel and reflux condenser. One hundred and fifty $\mathrm{ml}$ of pentane was added and the divinylmercury $(125 \mathrm{~g}$, 0.49 mole) introduced drop-wise. The mixture was then refluxed for one hour, allowed to settle and the mercury filtered off. The resulting solution was used for vinylation reactions.

Lithium wire or small pieces of metal may also be used. In this case, a light yellow, solid material remained after the removal of the solvent which could not be obtained in a crystalline form. Yields based on the formation of ethylene upon hydrolysis were between 70 and $80 \%$. Vinylsodium and vinylpotassium were prepared in the same manner.

B. Vinylalkalimetal compounds prepared by reacting an alkali metal with a vinyl halide: A dispersion containing $46 \mathrm{~g}$ ( 2 moles) of sodium and $350 \mathrm{ml}$ heptane was cooled to about $-18{ }^{\circ} \mathrm{C}$ and $107 \mathrm{~g}$ ( 1 mole) of vinylbromide was then very slowly added with stirring. Addition required approximately three hours. The reaction mixture had a dark blue color and was quite viscous. The highest yield (based on the formation of ethylene upon hydrolysis) was $65 \%$. Vinyllithium and vinylpotassium were prepared by the same method.

Solvents used in the reactions described above, were diethyl ether, tetrahydrofuran, pentane, hexane, heptane, benzene, and toluene. Reactions in which ether or tetrahydrofuran is used should be run at -50 to

7 L. Maier, D. Seyferth, F. G. A. Stone and E. G. Rochow, JACS 79, 5884 [1957].

8 B. Bartocha and P. J. Slota, jr., (to be published). 
$-40{ }^{\circ} \mathrm{C}$ to prevent dehydrohalogenation. This was noticed when acetylene was formed together with ethylene when a sample was hydrolyzed.

\section{Preparation of Vinylboron Dihalides}

Boron trichloride ( $11.7 \mathrm{~g}, 0.1$ mole) was condensed onto $11.3 \mathrm{~g}$ (0.095 mole) of divinylzinc and the mixture very slowly warmed to room temperature. Upon completion of the reaction, the resulting mixture was purified by distillation. Thus, at $45^{\circ} \mathrm{C} / 750 \mathrm{~mm} \mathrm{Hg}, 6.3 \mathrm{~g}$ $(61 \%)$ of vinylboron dichloride was obtained.

Anal. Calcd. for $\mathrm{C}_{2} \mathrm{H}_{3} \mathrm{BCl}_{2}$ : $\quad$ C 22.1 H 2.78 Cl 65.20. Found:

C 21.7 H 2.43 Cl 65.85 .

Boron tribromide, $15.0 \mathrm{~g}$ (0.06 mole), was condensed on $12.5 \mathrm{~g}$ ( 0.05 mole) divinylmercury and the mixture allowed to warm to room temperature and to stand for some time. The reaction products were then purified by distillation at reduced pressure. Boiling at $35^{\circ} \mathrm{C} /$ $50 \mathrm{~mm} \mathrm{Hg}, 8.1 \mathrm{~g} \mathrm{(82 \% )}$ of vinylboron dibromide was obtained.

Anal. Calcd. for $\mathrm{C}_{2} \mathrm{H}_{3} \mathrm{BBr}_{2}$ :

Found:

C 12.2 H 1.53 Br 80.8. C $11.8 \mathrm{H} 1.33 \mathrm{Br} 81.0$.

Preparation of Vinylphosphorus Halides

Vinyldibromophosphine: $13.5 \mathrm{~g}$ (0.05 mole) of phosphorus tribromide and $12.7 \mathrm{~g}(0.05 \mathrm{~mole})$ of divinylmercury were heated in Nujol at $80^{\circ}$ for 12 hours with stirring, after which vacuum was applied and a liquid, smoking in air was collected. It was redistilled at $60{ }^{\circ} \mathrm{C} / 20 \mathrm{~mm} \mathrm{Hg}$. Yield: $8.5 \mathrm{~g}$ (78\%).

Anal. Calcd. for $\mathrm{C}_{2} \mathrm{H}_{3} \mathrm{PBr}_{2}$ :

C 11.03 H 1.39 P 14.22 Br 73.37. C 10.9 H 1.23 P 13.9 Br 74.8 .
When tetravinyllead and phosphorus tribromide were heated in Nujol, in addition to $85 \%$ of $\mathrm{ViPBr}_{2}$, nearly a theoretical amount of divinyllead dibromide, $\mathrm{Vi}_{2} \mathrm{PbBr}_{2}$, was isolated. The white crystals melted above $300{ }^{\circ} \mathrm{C}$.

Anal. Calcd. for $\mathrm{C}_{4} \mathrm{H}_{6} \mathrm{PbBr}_{2}$ :

Found:

C $11.41 \mathrm{H} 1.44 \mathrm{~Pb} 49.2 \mathrm{Br} 38.0$. C 11.29 H 1.46 Pb 48.7 Br 37.7.

Divinylchlorophosphine: $12.8 \mathrm{~g} \quad(0.1 \mathrm{~mole})$ of vinyldichlorophosphine, $\mathrm{ViPCl}_{2}$, (prepared from tetravinyllead and phosphorus trichloride) was heated with $8.0 \mathrm{~g}$ $(0.025$ mole $)$ of tetravinyllead in $150 \mathrm{ml}$ pentachloroethane to about $110^{\circ}$ for 10 hours while stirring. After this time, no more tetravinyllead could be detected and the mixture was distilled. At $38-42{ }^{\circ} \mathrm{C} / 20 \mathrm{~mm} \mathrm{Hg}$, $5.2 \mathrm{~g}(43 \%)$ of divinylchlorophosphine, $\mathrm{Vi}_{2} \mathrm{PCl}$, was obtained.

Anal. Calcd. for $\mathrm{C}_{4} \mathrm{H}_{6} \mathrm{PCl}$ :

C 39.86 H 5.02 P $25.70 \mathrm{Cl} 29.42$.

Found:

C $39.1 \quad H$ 4.5 P 25.0 Cl 30.3.

In this reaction, $8.0 \mathrm{~g}(96.3 \%)$ of divinyllead dichloride, $\mathrm{Vi}_{2} \mathrm{PbCl}_{2}$, was also obtained. It is a white crystalline material melting above $300{ }^{\circ} \mathrm{C}$.

Anal. Calcd. for $\mathrm{C}_{4} \mathrm{H}_{6} \mathrm{PbCl}_{2}$ :

C $14.46 \mathrm{H} 1.82 \mathrm{~Pb} 62.37 \mathrm{Cl} 21.35$.

Found: $\quad$ C 14.0 H $1.6 \quad$ Pb 61.1 Cl 22.5

We wish to thank Dr. Charles P. Haber for his helpful suggestions during the course of this work. The research was supported jointly by the Bureau of Ordnance and Bureau of Ships, Department of the Navy, through their Foundational Research Program.

\title{
Uber Ferrocen und verwandte Verbindungen
}

Mitt. IV ${ }^{1}$ : Eine einfache Methode zur Gewinnung von Ferrocen

\author{
Von R. Riemschneider und D. Helm ${ }^{2}$ \\ Aus der Freien Universität Berlin-Dahlem \\ (Z. Naturforschg. 14 b, 811-814 [1959]; eingegangen am 3. Juni 1959)
}

\begin{abstract}
Es wird eine Versuchsanordnung beschrieben, die es gestattet, Ferrocen durch Uberleiten von Cyclopentadien über erhitztes Eisen(II) -oxalat darzustellen. Diese Methode kann auf geeignete Substitutionsprodukte des Cyclopentadiens sowie auch auf manche Schwermetallsalze übertragen werden.
\end{abstract}

Seit geraumer Zeit bedienen wir uns in unserem Laboratorium zur Gewinnung von Ferrocen einer Methode, bei der Cyclopentadien über erhitztes bzw. in Zersetzung befindliches Eisen(II)-oxalat geleitet wird. Dieses einstufig arbeitende Verfahren bietet

1 Mitt. I, R. Riemschneider u. D. Helm, Chem. Ber. 89, 155 [1956]; Mitt. II, R. Riemschneider, Dtsch. Bundes-Pat. Anm. R 20398 IV b/12 o vom 24. 1. 1957; Mitt. III, R. Riemschneider, Mh. Chem. 90, 658 [1959]. gegenüber anderen bekannten Methoden verschiedene Vorteile. Insbesondere erfordert es bei verhältnismäßig geringem apparativem Aufwand als Ausgangsstoffe nur Cyclopentadien und das wohlfeile, handelsübliche Eisen(II)-oxalat. Es werden weder

2 Anschrift für den Schriftverkehr: Prof. Dr. R. RiemschnerDER, Berlin-Charlottenburg 9, Bolivarallee 8. 